\title{
The fibrinolytic system facilitates tumor cell migration across the blood-brain barrier in experimental melanoma brain metastasis
}

\author{
George Perides ${ }^{1}$, Yuzheng Zhuge ${ }^{2}$, Tina Lin ${ }^{3}$, Monique F Stins ${ }^{4}$, \\ Roderick T Bronson ${ }^{5}$ and Julian $\mathrm{K} \mathrm{Wu}^{* 6}$
}

\begin{abstract}
Address: ${ }^{1}$ Department of Surgery, Division of Neurosurgery, Beth Israel Deaconess Medical Center, Harvard Medical School, and Department of Surgery, Tufts-New England Medical Center, Tufts University School of Medicine, Boston, MA, USA, ${ }^{2}$ Department of Surgery, Division of Neurosurgery, Beth Israel Deaconess Medical Center, Harvard Medical School, Boston, MA, USA, ${ }^{3}$ Department of Surgery, Division of Neurosurgery, Beth Israel Deaconess Medical Center, Harvard Medical School, Boston, MA, USA, ${ }^{4}$ The Johns Hopkins University School of Medicine, Baltimore, MD, USA, ${ }^{5}$ Dana-Farber-Harvard Cancer Center, Harvard Medical, Boston, MA, USA and ${ }^{6}$ Department of Surgery, Division of Neurosurgery, Beth Israel Deaconess Medical Center, Harvard Medical School, and Department of Neurosurgery, Tufts-New England Medical Center, Tufts University School of Medicine, Boston, MA, USA
\end{abstract}

Email: George Perides - gperides@tufts-nemc.org; Yuzheng Zhuge -yu8zheng@yahoo.com; Tina Lin - tlin@mah.harvard.edu; Monique F Stins - mstins@jhmi.edu; Roderick T Bronson - roderick_bronson@hms.harvard.edu; Julian K Wu* - jwu3@tufts-nemc.org

* Corresponding author

Published: 09 March 2006

BMC Cancer2006, 6:56 doi:10.1 186/147|-2407-6-56
Received: 19 September 2005

Accepted: 09 March 2006

This article is available from: http://www.biomedcentral.com/I47I-2407/6/56

(C) 2006Perides et al; licensee BioMed Central Ltd.

This is an Open Access article distributed under the terms of the Creative Commons Attribution License (http://creativecommons.org/licenses/by/2.0), which permits unrestricted use, distribution, and reproduction in any medium, provided the original work is properly cited.

\begin{abstract}
Background: Patients with metastatic tumors to the brain have a very poor prognosis. Increased metastatic potential has been associated with the fibrinolytic system. We investigated the role of the fibrinolytic enzyme plasmin in tumor cell migration across brain endothelial cells and growth of brain metastases in an experimental metastatic melanoma model.
\end{abstract}

Methods: Metastatic tumors to the brain were established by direct injection into the striatum or by intracarotid injection of BI6FI0 mouse melanoma cells in C57BI mice. The role of plasminogen in the ability of human melanoma cells to cross a human blood-brain barrier model was studied on a transwell system.

Results: Wild type mice treated with the plasmin inhibitor epsilon-aminocaproic acid (EACA) and $\mathrm{plg}^{-/}$mice developed smaller tumors and survived longer than untreated wild type mice. Tumors metastasized to the brain of wild type mice treated with EACA and $\mathrm{plg}^{-/}$less efficiently than in untreated wild type mice. No difference was observed in the tumor growth in any of the three groups of mice. Human melanoma cells were able to cross the human blood-brain barrier model in a plasmin dependent manner.

Conclusion: Plasmin facilitates the development of tumor metastasis to the brain. Inhibition of the fibrinolytic system could be considered as means to prevent tumor metastasis to the brain.

\section{Background}

There are about 150,000 metastatic brain tumors diagnosed annually compared to 17,000 primary brain tumors in the United States and the incidence of CNS metastases is steadily increasing [1-4]. While advances in cancer therapy have translated into longer survival for patients with extraneural disease, these advances have, ironically, increased the number of patients who develop 
CNS metastases. Despite decades of intensive investigation, and increasing success in treating extraneural cancer, the median survival for patients with CNS metastases from systemic cancer is only 6-10 months [5]. In patients with CNS metastasis, neurologic disease is the primary cause of disability in approximately half of the cases when treated with whole brain radiation and a third of the cases if treated with surgery and whole brain radiation [6]. Therefore, many patients experience significant disabilities in the final weeks of life. CNS metastases are also an important cause of disease relapse following high-dose chemotherapy with bone marrow or stem cell support [7] and a common reason for exclusion of patients from highdose chemotherapy protocols because of poor penetration of drugs into the CNS. For these reasons, strategies for preventing CNS metastases and growth from systemic cancer are vitally important.

Successful metastasis, depends on extracellular matrix remodeling which in turn depends on proteolytic enzymes [8]. Plasmin, a key component of the fibrinolytic system is a promiscuous serine protease which directly digests collagen, laminin, fibronectin, and proteoglycans in the extracellular matrix and indirectly by activating other matrixolytic enzymes (e.g. matrix metalloproteinases). Plasmin is generated after activation of plasminogen by urokinase- and tissue-type plasminogen activator (uPA and tPA) $[9,10]$. UPA and tPA in turn can be inhibited by the plasminogen activator inhibitors -1 and -2 . Melanoma is an excellent model to study the role of the fibrinolytic system since it has a high propensity for brain metastasis. Forty eight percent of patients with malignant melanoma develop brain metastasis [11]. The central nervous system appears to be a sanctuary for cancer cells in patients being treated with most systemic cytotoxic chemotherapies and immunotherapies. Consequently, as the systemic therapy for metastatic melanoma improves, CNS relapse is becoming more frequent and a major barrier to long term survival. The median survival of patients with melanoma metastatic to the central nervous system is less than six months.

\section{Methods \\ Cell culture}

B16F10 mouse melanoma cells and SK-Mel human melanoma cells were cultured in Dulbecco's modified Eagle's medium (DMEM) and 10\% fetal calf serum (FCS). Human brain microvascular endothelial cells (BMEC) were prepared as described previously [12]. The cells were maintained in DMEM:Ham's F12 (1:1) containing 10\% FCS (Invitrogen, Carlsbad, CA) and 10\% Nu serum (BioWhittaker, Inc. Walkersville, MD).

\section{Cell labeling}

Radioactive labeling of BI 6FIO mouse melanoma cells

Half a million B16F10 cells were plated in $100 \mathrm{~mm}$ petri dishes and left to grow for 48 hours in DMEM/F12 containing $10 \%$ fetal calf serum. The medium was removed and serum starved for 24 hours after which the medium was exchanged and $10 \mathrm{ml}$ of DMEM/F12 containing $1 \mu \mathrm{Ci}$ of 125 I-deoxyuridine (Perkin Elmer Boston, MA) was added. The next day the medium was removed and the cells washed with DMEM/F12 and used for further experiments.

\section{Labeling with Cell Tracker Orange ${ }^{\mathrm{TM}}$ (Molecular Probes, Eugene, \\ OR)}

Cells were plated in $100 \mathrm{~mm} ø$ petri dishes to reach confluence. They were then washed with DMEM/F12 and 5 ml DMEM/F12 containing $10 \mu \mathrm{M}$ Cell Tracker Orange ${ }^{\mathrm{TM}}$ and incubated for $40 \mathrm{~min}$ at $37^{\circ} \mathrm{C}$ in a $5 \% \mathrm{CO}_{2}$ and $100 \%$ humidity. Cells were washed with DMEM/F12 and incubated for another $40 \mathrm{~min}$. to allow the Cell Tracker Orange $^{\mathrm{TM}}$ to be incorporated.

\section{In vitro blood-brain barrier model}

To create an in vitro model of the human blood-brain barrier (BBB), 50,000 human BMEC were seeded on top of semipermeable Transwell ${ }^{\mathrm{TM}}$ polycarbonate tissue culture inserts (pore size $8 \mu \mathrm{m}, 6.5 \mathrm{~mm} \varnothing$ ) (Corning Costar Corp. Corning, NY). After 3 days the human BMEC formed a continuous monolayer [13]. At this point the transendothelial electrical resistance (TEER) of this monolayer was usually around $300-500 \mathrm{Ohm} / \mathrm{cm}^{2}$. The TEER was maintained at this level for the next 5-7 days. The TEER then declined and soon thereafter cells appeared to detach from the monolayer. For our experiments only monolayers with TEER greater than $300 \mathrm{Ohm} / \mathrm{cm}^{2}$ were used.

\section{Melanoma cell migration across BMEC}

SK-Mel cells labeled with Cell Tracker Orange ${ }^{\mathrm{TM}}$, were plated on the top of the BMEC monolayer in DMEM/F12. As a chemo-attractant DMEM/F12 containing 10\% FCS was added to the bottom chamber. The next day the inserts were examined for the presence and the location of the cancer cells. The top site of the insert was cleaned with a Q-tip swab and the remaining cells photographed and counted. To ensure that these cells had crossed the BMEC monolayer the bottom site of the insert was also cleaned with a Q-tip. Cells that were not removed by the Q-tip were not considered as having successfully crossed the BMEC monolayer.

\section{Animal tumor models}

Plasminogen heterozygous mice in a C57Bl background were a kind gift from Dr. Carmeliet (Vlaams Interuniversitair Institut voor Biotechnologie, Leuven, Belgium) [14]. They were further backcrossed 6 times to commercially 
available C57Bl (Jackson Laboratories, Bar Harbor, ME) and then intercrossed to generate wild type, heterozygous and homozygous plasminogen deficient mice. Plasminogen deficient mice have a limited lifespan (6-8 months) and are not efficient breeders and the colony is maintained by crossing the heterozygous mice. For our experiments 8-12 week old wild type and homozygous deficient mice were used while the heterozygous mice were kept to propagate the colony.

\section{Intracarotid injection of tumor cells}

To simulate hematogenous metastases to the brain we employed an intracarotid tumor injection model in the C57Bl mouse. Our intracarotid injection model is similar to the one described by Schackert and Fidler [15]. Modifications include a) we used a $30 \mathrm{G}$ needle to inject the cells instead of a glass needle, and b) we sutured the site of injection in the carotid artery to restore the blood circulation. C57B mice were anesthetized with $50 \mathrm{mg} / \mathrm{kg}$ xylazine $5 \mathrm{mg} / \mathrm{kg}$ ketamine cocktail. Mice were prepped with betadine and all operation took place under the dissecting microscope. A $1 \mathrm{~cm}$ incision in the neck was performed and the left common carotid artery was exposed. The external carotid artery was temporarily occluded with a 60 prolene and the common carotid artery was temporarily ligated with a microclip (George Tiemann, Hauppauge, NY). A 30 G needle connected to PE-10 tubing (Becton Dickinson, San Diego, CA) was inserted into the lumen of the common carotid artery. The $5 \mu \mathrm{l}$ cell suspension was then injected and chased with $40 \mu \mathrm{l}$ of Hanks balanced salt solution over a period of 1 minute. Distal to the needle a microclip was placed and the needle removed. The artery was sutured with a 10-0 prolene (Johnson \& Johnson, Sommerville, NJ) and the microclips removed to reestablish the blood flow. In most cases no bleeding was observed but if there was some it could be stopped with gentle pressure on the arteriotomy for 30-60 seconds. Mice were returned to their cage with unlimited access to food and water. More than $90 \%$ of the mice recovered completely after the surgery and without any neurological signs.

\section{Intracranial injection of tumor cells}

Anesthetized mice were placed in a stereotactic frame Kopf (Tujunga CA) prepped with betadine and a $0.5 \mathrm{~cm}$ incision was performed along the midline of the skull. Two mm left of the bregma a burr hole was drilled and tumor cells were injected $3 \mathrm{~mm}$ deep in the striatum over the course of $5 \mathrm{~min}$. Cells were resuspended in DMEM/ F12 at a concentration of $2 \times 10^{8} / \mathrm{ml}$ and $5 \mu \mathrm{l}$ were injected at a $1 \mu \mathrm{l}$ per minute rate. After injection the needle was left in the striatum $5 \mathrm{~min}$ and then it was removed. The skin was sutured and the animals returned to their cage with unlimited access to food and water.

\section{Results \\ Fate of intracarotid injected mouse melanoma cells}

To determine the fate of the injected cells we labeled B16F10 cells with ${ }^{125}$ I-deoxyuridine. ${ }^{125}$ I-deoxyuridine is incorporated in the DNA of the B16F10 cells and is not taken up by other mouse cells after injection [16]. It is then secreted in the urine. As reported earlier [17] the number of cells that remains in the brain rapidly decreases after the injection over the course of hours to days. Only a small percentage $(0.69+/-0.23 \%)$ was found in the brain after 72 hours (Fig. 1A). These cells remained stable over the course of ten days suggesting that the detected radioactivity in the brain was from living cells that gave rise to the subsequent tumors. The organs with the next highest level of radioactivity were the lungs followed by the kidney and the spleen. The levels of radioactivity in these organs however, continued to decline over the course of the next 10 days indicating that it represents dying cells. This interpretation was further supported by the absence of tumors in any of these organs two weeks after surgery. The only tumors identified were in the brain. On occasion, tumors were seen growing in the neck of these animals at the site of injection indicating that some cells had either leaked during the procedure or adhered to the carotid artery. Histologic examination of the hematoxylin-eosin stained brain section from wild type mice indicated that the cells were lodged in the blood vessels (Fig. 1B). From the blood circulation the cells extravasated into the brain (Fig. 1B, C). Once there, the tumors started growing into large masses (Fig. 1D) that often occupied large areas of the brain frequently as much as $25 \%$ of the brain volume depending on the time of incubation and the number of cells injected.

\section{Role of plasminogen in metastatic tumors to the brain}

With the knowledge that we could reproducibly obtain brain metastases in our intracarotid mouse model we then set out to determine whether the fibrinolytic system plays a role in the tumor metastasis to the brain. We injected 100,000 B16F10 cells in the carotid artery of wild type mice and mice lacking plasminogen $\left(\mathrm{plg}^{-/}\right)$. After 14 days all mice (wild type, and $\mathrm{plg}^{-/}$) were sacrificed and the brains removed and fixed in $4 \%$ paraformaldehyde overnight. The brains were cut in $2 \mathrm{~mm}$ slices embedded in paraffin and sections were obtained every $200 \mu \mathrm{m}$ intervals. Sections were stained with hematoxylin and eosin and photographed with a SPOT camera mounted on a Nikon E800 eclipse microscope. The tumor volume was calculated by integrating the tumor area with the length of the tumor. The tumor volume in $p l g-$ mice was $44.5 \%$ smaller than the tumor volume found in the brains of wild type mice (Fig. 2A). To ensure that the difference in survival was not due to genetic abnormalities that occurred with the genetic manipulations to generate the knockout animals, wild type mice were also treated with 

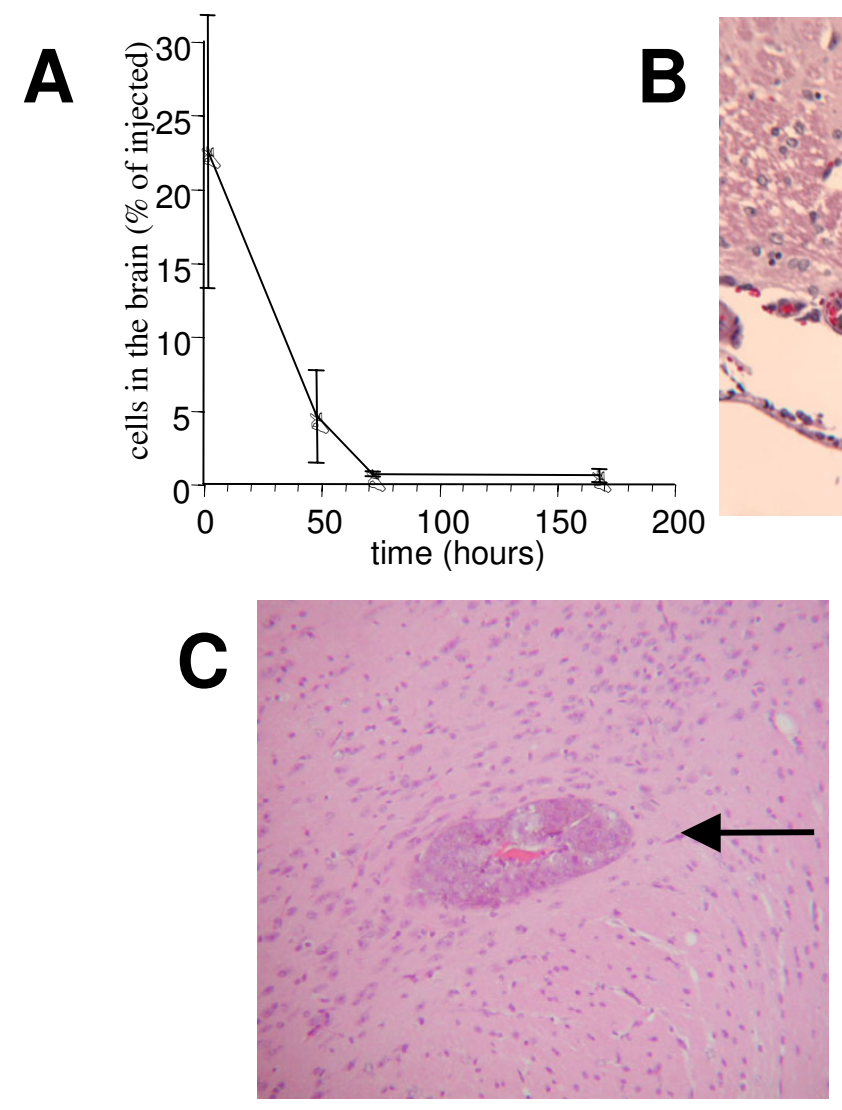
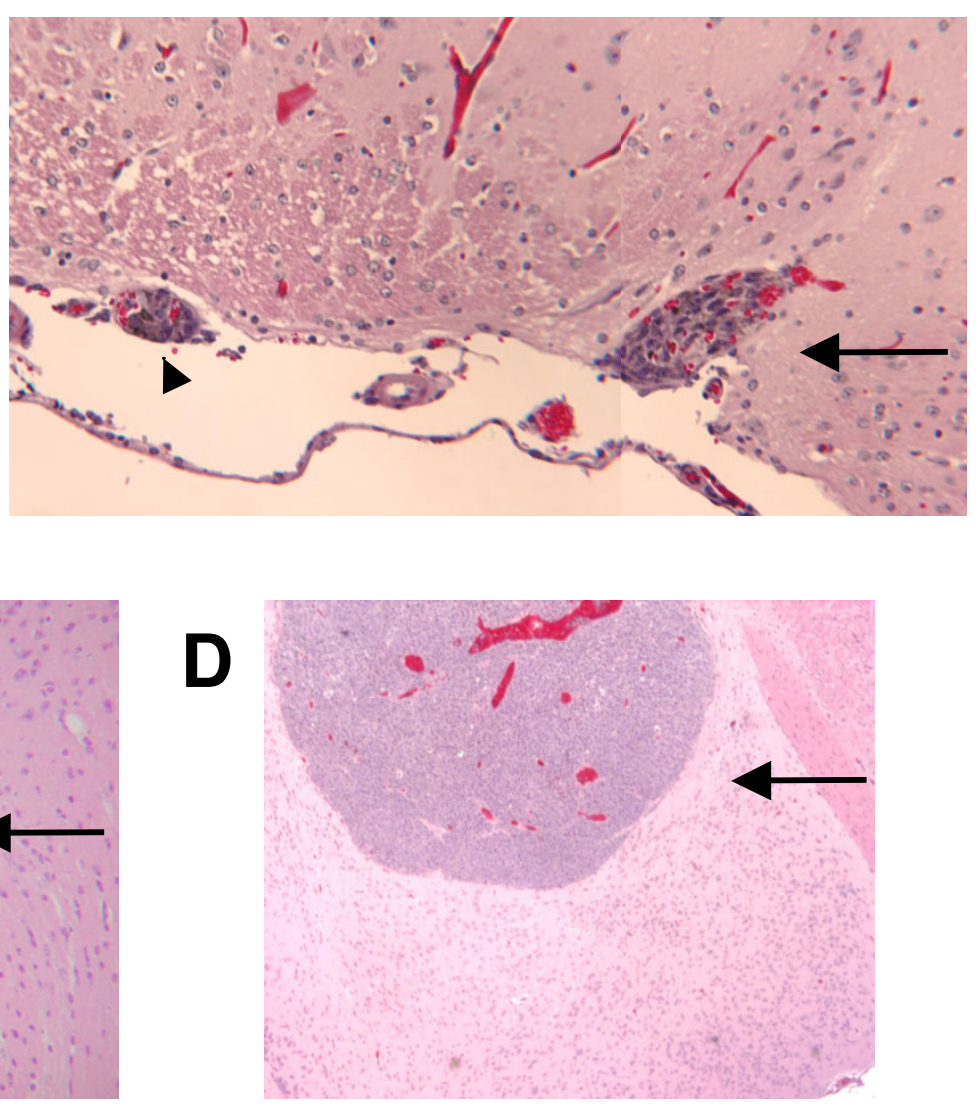

\section{Figure I}

Metastatic brain tumor model. A) One hundred thousand 125 -deoxyuridine-labeled BI6FI0 cells were injected in the left internal carotid artery. Mice were sacrificed after I, 24, and 48 hours, 3 days and 7 days. The left hemisphere was removed and the amount of radioactivity was measured by means of the ICN gamma-counter to determine the number of cells remaining in the brain. Note the rapid decline of radioactivity in the brain that remained stable after 72 hours. Hematoxylin-eosin staining of melanoma tumors developing in the brain after intracarotid injection (B-D). B) BI6FI0 cells lodged in a blood vessel (arrowhead) and cells invading the brain (arrow). C) BI6FIO cells (arrow) growing in the brain parenchyma. D) Large tumor growing in the brain parenchyma (arrow).

the plasmin inhibitor $\varepsilon$-aminocaproic acid (EACA). Two and a half percent of EACA was added in the water of the mice two days prior to the operation and it was changed daily. At this concentration the EACA levels in the blood is $275-300 \mu \mathrm{g} / \mathrm{ml}$ that completely inhibits the conversion of plasminogen to plasmin $[18,19]$. The tumor volume was $42.4 \%$ smaller than the tumor seen in wild type mice which would add support to our finding that plasminogen most likely participate in tumor metastasis to the brain of the $\mathrm{plg}^{-/- \text {mice }}$ (Fig. 2A).

We then determined whether the reduction in tumor burden translates into increased survival. In these experiments the 12 wild type mice died, on average after 16.9+/ -1.6 days compared to the $11 \mathrm{plg}-$ - mice that died on aver- age after $19.2+/-1.9$ days. The 7 EACA treated wild type mice also survived longer $(18.8+/-1.3$. days $)$ than the untreated wild type mice. Kaplan-Meyer analysis showed these differences are statistically significant (log rank test, $\mathrm{p}<0.03$ ) (Fig. 2B).

The observed differences in tumor size and mouse survival could be due to the effects of the fibrinolytic system in tumor growth and/or the process of metastasis. We first tested whether the fibrinolytic system affects tumor growth directly in the brain by bypassing the blood-brain barrier. We injected 100,000 B16F10 cells directly in the striatum of wild type mice, wild type mice treated with EACA and $\mathrm{plg} /$ - mice. Twelve days after tumor cell implantation the mice were sacrificed and the brains removed to 

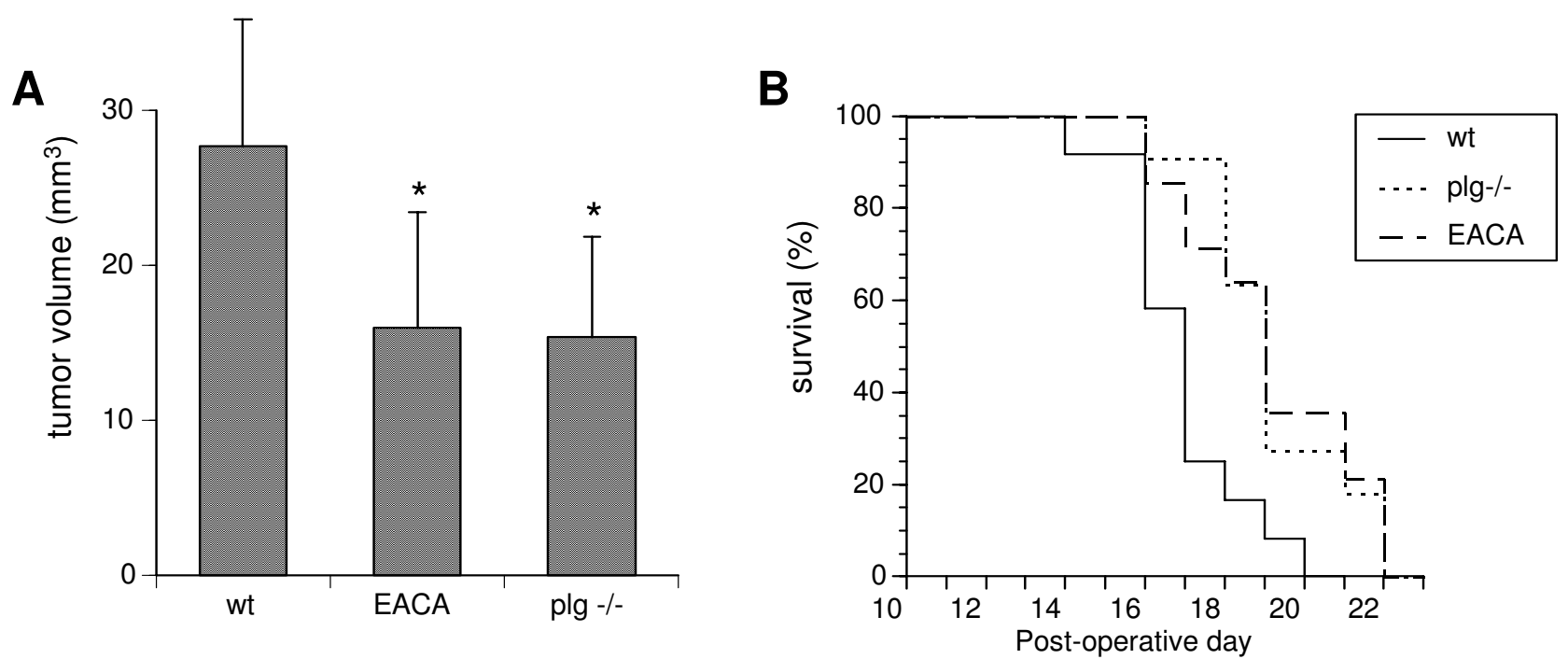

\section{Figure 2}

Effect of plasminogen in tumor metastasis. Metastatic brain tumors were established by injecting $10^{6} \mathrm{BI} 6 \mathrm{FI} 0$ cells in the left internal carotid artery of wild type wild type C57BI (wt), plasminogen deficient (plg-/-) and wild type mice treated with EACA (EACA). Fourteen days after tumor cell injection the mice were sacrificed the brains removed fixed and stained with hematoxylin eosin. The areas of the tumors at $200 \mu \mathrm{m}$ intervals were measured and the total volume of the tumor determined. Note the reduced tumor size in mice treated with EACA and plg-/- mice compared to wild type mice. B) Survival graph of I2 wild type mice (wt), II plg/- mice (plg-/-) and 7 wild type mice treated with EACA (EACA) injected with $10^{6} \mathrm{BI} 6 \mathrm{FI}$ cells. Note the increased survival of $\mathrm{plg}^{-/-}$and wild type mice treated with EACA compared to untreated wild type mice $(p<0.03)$

determine the volume of the growing tumors. No statistically significant difference in the size of these tumors was observed (Fig. 3A).

To determine whether the difference in tumor volume was due to the difference in the number of tumor cells metastasizing to the brain we labeled B16F10 cells with ${ }^{125}$ Iiodo-2'-deoxyuridine and injected them into the internal carotid artery. Seventy two hours after injection mice were sacrificed, the brains removed and the radioactivity measured to determine the number of cells. Plasminogen deficient $\left(\mathrm{plg}^{-/}\right)$mice had $0.30 \%+/-0.1$ of the initially injected cells in the brain compared to $0.69 \%$ in wild type mice a $53.3+/-14.4 \%$ reduction (Fig. 3B). Similarly, EACA treated mice contained $0.38 \%+/-0.22$ of the injected cells, $46.6 \%$ fewer cells compared to untreated wild type mice. Taken together these results suggest that the fibrinolytic system in particular plasmin is important in the establishment of the metastasis to the brain but not the growth of the tumor in the brain once it gets there.

\section{Melanoma cells crossing the blood-brain barrier model}

To further understand the role of the fibrinolytic system in tumor cell invasion of the brain we employed an in vitro blood-brain barrier model formed by human brain microvascular endothelial cells (BMEC) $[12,20]$. The BMEC are positive for FVIII-Rag, carbonic anhydrase IV, Ulex europeus agglutinin I and take up acetylated low-density lipoprotein (AcLDL) demonstrating their endothelial origin and also express gamma glutamyl transpeptidase, demonstrating their brain origin $[12,20]$. Brain endothelial cells with these phenotypic expression were previously immortalized by transfection with the SV40-large T-antigen [20]. To determine whether tumor cells were able to cross the blood-brain barrier model they were first labeled with Cell Tracker Orange (Molecular Probes, Eugene, OR). Human SK-Mel cells were placed on top of a monolayer formed by BMEC in the presence or absence of plasminogen and the presence or absence of the plasminogen inhibitor EACA and $\alpha_{2}$-antiplasmin. At the end of the experiment the cells were photographed and counted. In the absence of plasminogen virtually no cells crossed the BBB model $(0.56+/-0.3 \%)$. However, by adding human plasminogen a 9 -fold increase $(5.32+/-0.78 \%)$ in the number of cells crossing the BBB model was observed. By adding the plasminogen inhibitor EACA or $\alpha_{2}$-antiplasmin in addition to plasminogen we saw strong inhibition of the plasminogen-dependent inhibition of tumor cell 
A

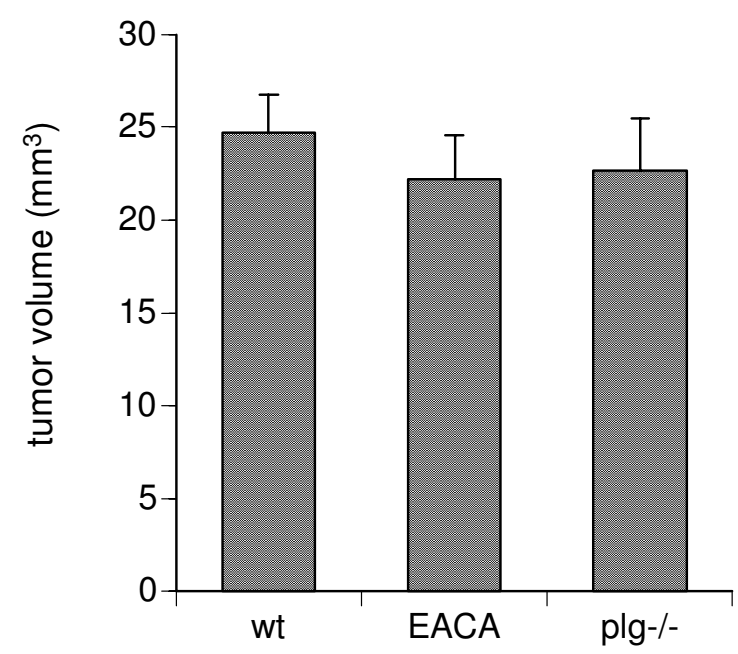

B

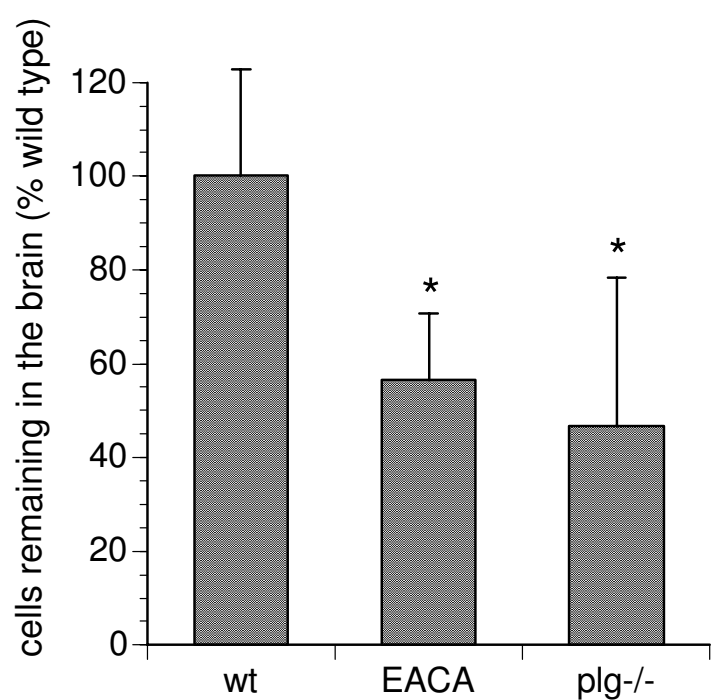

\section{Figure 3}

Plasminogen facilitates the process of metastasis but not tumor growth in the brain. A) Ten thousand BI6FI0 cells were injected in the striatum of 5 wild-type mice (control), 5 plg/- mice (plg-/-) and 5 wild type mice treated with EACA (EACA). The mice were sacrificed 12 days after tumor cell injection and the brains removed to determine the size of the growing tumor (bars show the standard deviation). No statistically significant difference between the three groups was observed. B) Wild-type mice (wt),plg/- mice and wild type mice treated with EACA (EACA) were injected with 100,000 I25I-deoxyuridine labeled BI6FIO cells in the internal carotid artery. They were sacrificed 3 days later and their brains removed to determine the amount of radioactivity and compared to the total amount radioactivity injected in these mice. The bars represent the average of six mice for each group (bars show the standard deviation). The amount of radioactivity found in the wild type mice was considered as $100 \% * \mathrm{p}<0.01$.

migration across the BBB $(0.85+/-0.26 \%$ and $0.89+/-$ $0.32 \%$, respectively) indicating that plasminogen is necessary for crossing of the BBB model (Fig. 4).

\section{Discussion}

Since the first correlation between cancer and plasminogen activation was drawn more than 25 years ago [21] there has been more than 100 reports on the prognostic value of uPA, tPA and the plasminogen activator inhibitor -1 (PAI-1) (reviewed in [22-24]. Several studies on experimental tumor models have been published suggesting that inhibition of fibrinolytic enzymes can inhibit tumor growth and metastasis [25-27]. EACA, a plasmin inhibitor, reduced tumor growth by $37 \%$ in a xenograft tumor model of glioma [18]. A synthetic inhibitor trans-4-amino ethylcyclohexanecarbonyl-tyr-(O-Pic)-octylamide inhibited human lung metastasis in a xenograft mouse model [28]. Prostate carcinoma metastasis in a mouse model was prevented by a synthetic urokinase inhibitor [29]. A study using overexpression of uPA receptor in breast carcinoma showed increased invasion and metastasis suggesting a role of uPA in tumor growth [30]. Melanoma cells express uPA and UPA receptor which may facilitate activation plasmin [31]. In a survey of skin cancers the levels of uPA correlated with the malignancy of the tumors with malignant melanoma containing the highest amounts of uPA, followed by squamous cell carcinoma and basal cell carcinoma containing the least amount of uPA [32]. Inhibition of plasminogen and plasminogen activators reduced melanoma cell migration in an in vitro model [33]. Melanoma cells transfected with plasminogen activation inhibitor-1 developed fewer metastases than not transfected cells in a lung metastasis model [34] and in an ocular melanoma tumor model [35].

Brain metastases from systemic cancers are increasing despite advances in systemic treatments. In an attempt to dissect the underlying mechanisms for brain metastases we injected melanoma tumor cells directly into the carotid arteries of mice to establish a model for hematogenous metastases to the CNS. By manipulating the presence or absence of plasminogen with plasminogen knockout mice we demonstrated that in the absence of the expression of plasminogen the metastatic tumors were smaller and the survival of the corresponding mice were significantly longer. When we pretreated the wild type 


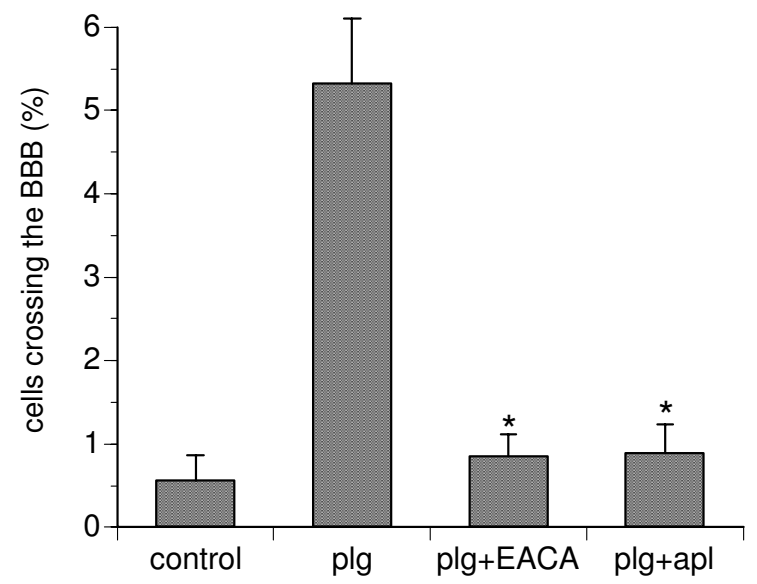

Figure 4

Cancer cell transversal of the in vitro blood-brain barrier model. 50,000 BMEC were plated on $6.5 \mathrm{~mm} \varnothing$ transwells coated with collagen and $8.0 \mu \mathrm{m}$ pore size in DMEM/FI $2 / 10 \% \mathrm{FCS} / 10 \%$ Nu serum. After 3 days the cells had grown to confluence and the medium was removed and replaced with DMEM/FI2. After two more days 10,000 human SK-melanoma cells (SK-Mel) labeled with CellTracker Orange ${ }^{\mathrm{TM}}$ were added. These co-cultures were further incubated in the absence of exogenous plasminogen (control), in the presence of I $\mu \mathrm{g} / \mathrm{ml}$ plasminogen (plg) and in the presence of plasminogen and EACA (EACA). The results are the average of three experiments performed in duplicate. Error bars show standard deviation. ${ }^{*} p<0.01$.

mice with EACA, a plasminogen inhibitor, prior to intracarotid injection of melanoma cells the brain metastases were also smaller and these animals survived longer similar to the plasminogen knockout mice. The smaller tumors in the EACA treated and plasminogen knockout mice could be due to inhibition of tumor growth in the brain once the melanoma cells reached there or inhibition of tumor cells moving across the blood-brain barrier. Our experiments with direct brain injections of tumor cells in the plasminogen knockout mice and EACA treated wild type mice showed no reduction of tumor size compared to the tumors in wild type mice. These results would suggest that plasmin is important in the migration of tumor cells across the blood-brain barrier into the brain parenchyma and not in the growth of the tumor once it is established in the brain. Plasmin can modulate cell adhesion by directly digesting tenascin as it has been shown in lymphocytes [36]. It can promote cell motility by regulating the interaction between vitronectin and uPA [37]. It can facilitate cell migration across the blood-brain barrier by directly digesting fibronectin and laminin [38,39]. In the brain parenchyma plasmin can interact and digest the L1cell adhesion molecules to disrupt cell adhesion [40]. In addition, to these direct effects, plasmin activates matrix metalloproteinases that in turn digest other extracellular matrix proteins or modulate gene expression of other genes [41]. To determine whether migration of tumor cells across the BBB is dependent on plasmin we utilized an in vitro BBB model using human brain microvascular endothelial cells (BMEC). These experiments demonstrated that the migration of human melanoma cells across the BMEC was dependent on plasmin. With inhibition of plasmin significantly fewer melanoma cells cross the BMEC. However, these in vitro studies do not take into account the possibility that tumor cells can simply get lodged in the capillaries and start proliferating there. Once they reach a critical mass the capillaries may simply break allowing the cells to enter the brain parenchyma.

\section{Conclusion}

Our experiments suggest that the fibrinolytic system is involved in facilitating melanoma cells cross of the bloodbrain barrier, but the minimal increase in animal survival, suggests that other enzymes may be involved. Studies suggest that matrix metalloproteinases (MMPs) and a disintegrin and metalloproteinase family of proteolytic enzymes (ADAMTS) may also play a role in the development of metastases [42,43]. In fact, inhibition of matrix metalloproteinases, leads to restoration of the bloodbrain barrier in an experimental autoimmune encephalomyelitis [44]. Further understanding of the mechanisms by which systemic cancers metastasize to the brain will enable us to devise novel methods to inhibit brain metastasis across the blood-brain barrier and improved survival for patients.

\section{List of abbreviations}

blood-brain barrier, BBB; brain microvascular endothelial cells, BMEC; central nervous system, CNS; Dulbecco's modified Eagle's medium, DMEM; epsilon-aminocaproic acid, EACA; fetal calf serum, FCS; plasminogen, plg; urokinase-type plasminogen activator, uPA; tissue-type plasminogen activator, tPA.

\section{Competing interests}

The author(s) declare that they have no competing interests.

\section{Authors' contributions}

GP designed the studies, performed intracranial injections and migration experiments, analyzed the data and prepared the manuscript. YZ performed intracarotid injections and migration experiments, TL performed intracarotid injections. MS developed the blood-brain barrier model, RB analyzed the histology slides, JKW analyzed the data and prepared the manuscript. All authors read and approved the manuscript. 


\section{Acknowledgements}

We are grateful to Joshi Sangeeta and Pranjal Patel for technical assistance and to Dr. P. Carmeliet for the $\mathrm{plg}^{-/-}$mice. These studies were supported by a grant from The Brain Tumor Society.

\section{References}

I. Levin VA, Sheline GE, Cutin PH: Neoplasms of the central nervous system. In Cancer Principles and Practice of Oncology 4th edition. Edited by: De Vita VTJ, Hellman S and Rosenberg SA. Philadelphia, J.B. Lippincott Company; I993:I679-I737.

2. Posner JB: Neurologic complications of cancer. Philadelphia, F.A. Davis Company; 1995.

3. Posner JB, Chernik NL: Intracranial metastases from systemic cancer. Adv Neurol 1978, 19:579-591.

4. Sawaya R, Bindal RK: Metastatic brain tumors. In Brain tumors Edited by: Kaye AH and Laws JER. Edinburgh, Churchill Livingstone 1995:923-946.

5. Arbit $\mathrm{E}$, Wronski $\mathrm{M}$ : Clinical decision making in brain metastases. Neurosurg Clinics North Am 1996, 7:447-457.

6. Patchell RA: The treatment of brain metastases. Cancer Invest 1996, I4:169-177.

7. Ayash LJ, Elias A, Schwartz G, Wheeler C, Ibrahim J, Teichler BA, Reich E, Warren D, Lynch C, Richardson P, Snipper L, Frei E, Antman $\mathrm{K}$ : Double dose of intensive chemotherapy with autologous stem cell support for metastatic breast cancer: no improvement in progression-free survival by the sequence of highdose melphalan followed by cyclophosphamide, thiotepa, and caboplatin. I Clin Oncol 1996, 14:2984-2992.

8. Thorgeirsson UP, Lindsay CK, Cottam DW, Gomez DE: Tumor invasion, proteolysis, and angiogenesis. I Neuro-Oncol 1994, 18:89-103.

9. Plow EF, Herren T, Redlitz A, Miles LA, Hoover-Plow JL: The cell biology of the plasminogen system. FASEB J 1995, 9:939-945

10. Vassalli JD, Sappino AP, Belin D: The plasminogen activator/plasmin system. J Clin Invest 1991, 88:1067-1072.

II. Sober AJ, Koh HK, Tran NLT, Washington CBJ: Melanoma and other skin cancers. In Harrison's Principles of Internal Medicine 14th edition. Edited by: Fauci AS, Braunwald E, Isselbacher J], D. WJ, Martin JB, Kasper DL, Hauser SL and Longo DL. New York, McGraw-Hill; 1998:543-549.

12. Stins MF, Gilles F, Kim KS: Selective expression of adhesion molecules on human brain microvascular endothelial cells. J Neuroimmunol 1997, 76:81-90.

13. Persidsky Y, Stins M, Way D, Witte MH, Weinand M, Kim KS, Bock $P$, Gendelman HE, Fiala M: A model for monocyte migration through the blood-brain barrier during HIV-I encephalitis. J Immunol 1997, I 58:3499-35 I0.

14. Ploplis VA, Carmeliet P, Vazirzadeh S, Van Vlaenderen I, Moons L, Plow EF, Collen D: Effects of disruption of the plasminogen gene on thrombosis, growth, and health in mice. Circulation 1995, 92:2585-2593.

15. Schackert G, Fidler IJ: Development of in vivo models for studies of brain metastasis. Int J Cancer 1988, 41:589-594.

16. Hughes WL, Commerford SL, Gitlin D, Krueger RC, Schultze B, Shah $\checkmark$, Reilly P: Deoxyribonucleic acid metabolism in vivo: cell proliferation and death as measured by incorporation and elimination of iododeoxyuridine. Fed Proc 1964, 23:640-648.

17. Schackert G, Price JE, Bucana CD, Fidler IJ: Unique patterns of brain metastasis produced by different human carcinomas in athymic nude mice. Int J Cancer 1989, 44:892-897.

18. Sawaya R, Mandybur T, Ormsby I, Tew JMJ: Antifibrinolytic therapy of experimentally grown malignant brain tumors. J Neurosurg 1989, 64:263-268.

19. Brockway WJ, Castellino FJ: The mechanism of the inhibition of plasmin activity by e-aminocaproic acid. The Journal of Biological Chemistry 197I, 246:464 I-4647.

20. Stins MF, Prasadarao NV, Zhou J, Arditi M, Kim KS: Bovine brain microvascular endothelial cells transfected with SV40-large $T$ antigen: development of an immortalized cell line to study pathophysiology of CNS disease. In Vitro Cell Dev Biol Anim I997, 33:243-247.

21. Butler WB, Kirkland WL, Jorgensen TL: Induction of plasminogen activator by estrogen in a human breast cancer cell line (MCF-7). Biochemical \& Biophysical Research Communications 1979, 90:1328-1334.
22. Duffy MJ, Duggan C, Maguire T, Mulcahy K, Elvin P, McDermontt E, Fennelly Jj, O'Higgins $\mathrm{N}$ : Urokinase plasminogen activator as a predictor of aggressive disease in breast cancer. Enzyme \& Protein 1996, 49:85-93.

23. Ronne E, Hoyer-Hansen G, Brunner N, Pedersen H, Rank F, Osborne CK, Clark GM, Dano K, Grondahl-Hansen J: Urokinase receptor in breast cancer tissue extracts. Enzyme-linked immunosorbent assay with a combination of mono- and polyclonal antibodies. Breast Cancer Res Treatm 1995, 33:199-207.

24. Schmitt M, Janicke F, Moniwa N, Chucholowski N, Pache L, Graeff H: Tumor-associated urokinase-type plasminogen activator: biological and clinical significance. Biol Chem Hoppe-Seyler 1992, 373:6II-622.

25. Bugge TH, Lund LR, Kombrinck KK, Nielsen BS, Holmback K, Drew AF, Flick MJ, Witte DP, Dano K, Degen JL: Reduced metastasis of Polyoma virus middle $T$ antigen-induced mammary cancer in plasminogen-deficient mice. Oncogene 1998, 16:3097-3 I04.

26. Praus M, Wauterickx K, Collen D, Gerard RD: Reduction of tumor cell migration and metastasis by adenoviral gene transfer of plasminogen activator inhibitors. Gene Ther 1999, 6:227-236.

27. Praus M, Collen D, Gerard RD: Both u-PA inhibition and vitronectin binding by plasminogen activator inhibitor I regulate HTI080 fibrosarcoma cell metastasis. Int J Cancer 2002, I02:584-59|.

28. Szende B, Okada Y, Tsuda Y, Horvath A, Bokonyi G, Okamoto S, Wanaka K, Keri G: A novel plasmin-inhibitor inhibits the growth of human tumor xenografts and decreases metastasis number. In Vivo 2002, I 6:28I-286.

29. Rabbani SA, Harakidas P, Davidson DJ, Henkin J, Mazar AP: Prevention of prostate-cancer metastasis in vivo by a novel synthetic inhibitor of urokinase-type plasminogen activator (uPA). International Journal of Cancer 1995, 63:840-845.

30. Xing RH, Rabbani SA: Overexpression of urokinase receptor in breast cancer cells results in increased tumor invasion, growth and metastasis. International Journal of Cancer 1996, 67:423-429.

31. Stetler-Stevenson WG: Progelatinase $\mathbf{A}$ activation during tumor cell invasion. Invasion Metastasis 1994, I 4:259-268.

32. Maguire T, Chin D, Souta D, Duffy MJ: Low levels of urokinase plasminogen activator components in basal cell carcinoma of the skin. International Journal of Cancer 2000, 85:457-459.

33. Stahl A, Mueller BM: Melanoma cell migration on vitronectin: regulation by components of the plasminogen activation system. International Journal of Cancer 1997, 71:116-122.

34. Ignar DM, Andrews JL, Witherspoon SM, Leray JD, Clay WC, Kilpatrick K, Onori J, Kost T, Emerson DL: Inhibition of establishment of primary and micrometastatic tumors by a urokinase plasminogen activator receptor antagonist. Clin Exp Metastasis 1998, 16:9-20.

35. Ma D, Gerard RD, Li XY, Alizadeh H, Niederkorn JY: Inhibition of metastasis of intraocular melanomas by adenovirus-mediated gene transfer of plasminogen activator inhibitor type I (PAI-I) in an athymic mouse model. Blood 1997, 90:2738-2746.

36. Gundersen D, Tran-Thang C, Sordat B, Mourali F, Ruegg C: Plasmininduced proteolysis of tenascin-C: modulation by $T$ lymphocyte-derived urokinase-type plasminogen activator and effect on $\mathrm{T}$ lymphocyte adhesion, activation, and cell clustering. J Immunol 1997, I 58:105 I-1060.

37. Waltz DA, Natkin LR, Fujita RM, Wei Y, Chapman HA: Plasmin and plasminogen activator inhibitor type I promote cellular motility by regulating the interaction between the urokinase receptor and vitronectin. I Clin Invest 1997, 100:58-67.

38. Barilla ML, Carsons SE: Fibronectin fragments and their role in inflammatory arthritis. Semin Arthritis Rheum 2000, 29:252-265.

39. Chen ZL, Strickland S: Neuronal death in the hippocampus is promoted by plasmin-catalyzed degradation of laminin. Cell 1997, $91: 917-925$.

40. Silletti S, Mei F, Sheppard D, Montgomery AM: Plasmin-sensitive dibasic sequences in the third fibronectin-like domain of LIcell adhesion molecule (CAM) facilitate homomultimerization and concomitant integrin recruitment. J Cell Biol 2000, | 49: | 485-1502.

41. Cairns RA, Khokha R, Hill RP: Molecular mechanisms of tumor invasion and metastasis: an integrated view. Curr Mol Med 2003, 3:659-67I. 
42. Arnold SM, Young AB, Munn RK, Patchell RA, Nanayakkara N, Markesbery WR: Expression of p53, bcl-2, E-cadherin, matrix metalloproteinase-9, and tissue inhibitor of metalloproteinases- $I$ in paired primary tumors and brain metastasis. Clin Cancer Res 1999, 5:4028-4033.

43. Shintani $Y$, Higashiyama $S$, Ohta M, Hirabayashi $H$, Yamamoto $S$, Yoshimasu T, Matsuda $\mathrm{H}$, Matsuura $\mathrm{N}$ : Overexpression of ADAM9 in non-small cell lung cancer correlates with brain metastasis. Cancer Res 2004, 64:4190-4I96.

44. Gijbels K, Galardy RE, Steinman L: Reversal of experimental autoimmune encephalomyelitis with a hydroxamate inhibitor of matrix metalloproteases. Journal of Clinical Investigation 1994, 94:2177-2182.

\section{Pre-publication history}

The pre-publication history for this paper can be accessed here:

http://www.biomedcentral.com/1471-2407/6/56/prepub

Publish with Biomed Central and every scientist can read your work free of charge

"BioMed Central will be the most significant development for disseminating the results of biomedical research in our lifetime. "

Sir Paul Nurse, Cancer Research UK

Your research papers will be:

- available free of charge to the entire biomedical community

- peer reviewed and published immediately upon acceptance

- cited in PubMed and archived on PubMed Central

- yours - you keep the copyright

Submit your manuscript here:

http://www.biomedcentral.com/info/publishing_adv.asp 